\title{
Posterior mini-incision total hip arthroplasty controls the extent of post-operative formation of heterotopic ossification
}

\author{
D. S. Edwards ${ }^{1,2,3}$ - S. A. R. Barbur ${ }^{3}$ A. M. J. Bull ${ }^{2}$ G. J. Stranks ${ }^{3}$
}

Received: 5 March 2015/Accepted: 16 April 2015/Published online: 8 May 2015

(C) The Author(s) 2015. This article is published with open access at Springerlink.com

\begin{abstract}
Heterotopic ossification (HO) is the formation of bone at extra-skeletal sites. Reported rates of $\mathrm{HO}$ after hip arthroplasty range from 8 to $90 \%$; however, it is only severe cases that cause problems clinically, such as joint stiffness. The effects of surgical-related controllable intraoperative risk factors for the formation of $\mathrm{HO}$ were investigated. Data examined included gender, age of patient, fat depth, length of operation, incision length, prosthetic fixation method, the use of pulsed lavage and canal brush, and component size and material. All cases were performed by the same surgeon using the posterior approach. A total of 510 cases of hip arthroplasty were included, with an overall rate of $\mathrm{HO}$ of $10.2 \%$. Longer-lasting operations resulted in higher grades of HO $(p=0.047)$. Incisions $>10 \mathrm{~cm}$ resulted in more widespread HO formation $(p=0.021)$. No further correlations were seen between HO formation and fat depth, blood loss, instrumentation, fixation methods or prosthesis material. The mini-incision approach is comparable to the standard approach in the aetiology of $\mathrm{HO}$ formation, and whilst the rate of $\mathrm{HO}$ may not be controllable, a posterior mini-incision approach can limit its extent.
\end{abstract}

Keywords Heterotopic ossification - Arthroplasty · Hip · Mini-incision · Posterior approach

D. S. Edwards

taffedwards100@hotmail.com

1 Royal Centre for Defence Medicine, Birmingham, UK

2 The Royal British Legion Centre for Blast Injury Studies, Imperial College London,

South Kensington, London SW7 2AZ, UK

3 Hampshire Hospitals NHS Trust, Basingstoke, Hampshire RG24 9NA, UK

\section{Introduction}

Heterotopic ossification (HO) is the formation of ectopic bone at extra-skeletal sites [1]. In the case of total hip arthroplasty (THA), it is commonly found in the periarticular capsule and surrounding muscular structures [2]. The rates of $\mathrm{HO}$ after hip arthroplasty have been reported to range from 8 to $90 \%[3,4]$. Brooker et al. [5] have discussed the risk factors for $\mathrm{HO}$ formation and developed a method of quantitative classification. It has been shown that grades 3 and 4, the final stage of ankylosis, are the most problematic for patients, commonly complaining of pain and a reduced range of movement [6]. Rates of severe $\mathrm{HO}$ range from 3 to $55 \%$ depending on patients and surgical factors present [7]. Established risk factors include male gender, diffuse idiopathic skeletal hyperostosis (DISH), ankylosing spondylitis, previous THA and subsequent HO formation, rheumatoid arthritis, osteonecrosis and previous trauma to the hip $[8,9]$. However, there exists little or weak evidence pertaining to the controllable intra-operative factors such as incision length, blood loss, length of operation, prosthesis type and instrumentation [3-5, 7, 8, 10].

Recent research investigating the effect of inflammation and local ischaemia on stem cell manipulation and subsequent $\mathrm{HO}$ formation has proposed the possibility that $\mathrm{HO}$ formation is likely to be stimulated by local and systemic factors contributing to the pathological picture $[1,11-16]$. In the case of THA, it is surgery itself that indicates the index event leading to HO. Therefore, the purpose of this study was to test the hypothesis that decisions made by the surgeon can influence HO formation following THA. This was done by identifying a large patient cohort, quantifying the current incidence and report on surgical and intra-operative factors that may predispose to the formation of HO. Our hypothesis is that factors that influence $\mathrm{HO}$ rates are 
surgical technique, including incision length, a measure of tissue trauma and intra-operative measures such as prosthetic fixation type, the use of pulsed lavage and canal brush, component size and material, and relevant patient variables, for example age, gender and fat depth.

\section{Methods}

An internal single hospital database was used, and consecutive THA patients performed by a single arthroplasty surgeon were retrospectively evaluated. Inclusion criteria for the study were as follows: a complete follow-up at 1 year with available radiographs of the operated hip, no prophylaxis of $\mathrm{HO}$ given and the availability of data (in the database or patient case notes or combined). Revision THA, THA for congenital hip disorders, trauma-related conditions and THA associated with osteotomy were excluded. Post-operative radiographs taken at 1 year were evaluated for the presence of $\mathrm{HO}$ and quantitatively scored as per Brooker's [5] classification (Table 1; Fig. 1). The

Table 1 Brooker's classification of heterotopic ossification of the hip joint [5]

\begin{tabular}{|c|c|}
\hline Score & Specification/region \\
\hline 0 & No HO on anteroposterior view of the hip \\
\hline Class 1 & Islands of bone within the soft tissues about the hip \\
\hline Class 2 & $\begin{array}{l}\text { Bone spurs from the pelvis or femur with }>1 \mathrm{~cm} \\
\text { between opposing ends }\end{array}$ \\
\hline Class 3 & $\begin{array}{l}\text { Bone spurs with reduced space between the opposing } \\
\text { bone surface of }<1 \mathrm{~cm}\end{array}$ \\
\hline Class 4 & Ankylosis of the hip joint \\
\hline
\end{tabular}

classification of Schmidt and Hackenbrock [17] was used to denote the anatomical site of the HO (Table 2). Table 3 lists the database variables analysed.

Data were assessed for normality using the ShapiroWilk test and the alpha value set for significance set at $p<0.05$. The study was registered with the local hospital trust Audit and Research Department. Gender, femur fixation method, femoral head size, acetabular diameter, the use of pulse lavage, blood loss, age, prosthesis material, anaesthetic type, operative time, fat depth and incision length were evaluated for $\mathrm{HO}$ formation (present/not present), grade (Brooker) and extent (Schmidt). The Chisquared test was used for categorical data, $t$ test for comparison of means between the $\mathrm{HO}$ and non-HO groups for numerical data and Pearson's correlation to demonstrate linear relationship between groups. Where significance was found in scalar data, Chi-squared test was used to determine significance from the mean.

\section{Results}

Post-exclusion, 510 cases were available for a 15-year period (Fig. 2). All cases included were performed by the same surgeon of Consultant grade (senior author-GJS) using the posterior approach to the hip. The average age of the cohort was 65.8 years (range 21.8-93.5 years, standard deviation 11.65 years). There were 221 (43.3\%) males and 289 females $(56.6 \%)$. Fifty-three patients $(10.4 \%)$ demonstrated evidence of $\mathrm{HO}$ at the 1-year follow-up radiograph with one demonstrating a Brooker grade 4, complete ankylosis (Table 4). The fixation method of the prostheses in 389 cases was uncemented $(76.3 \%)$ and 121 cases $(22.7 \%)$ cemented. Cobalt chrome was the most
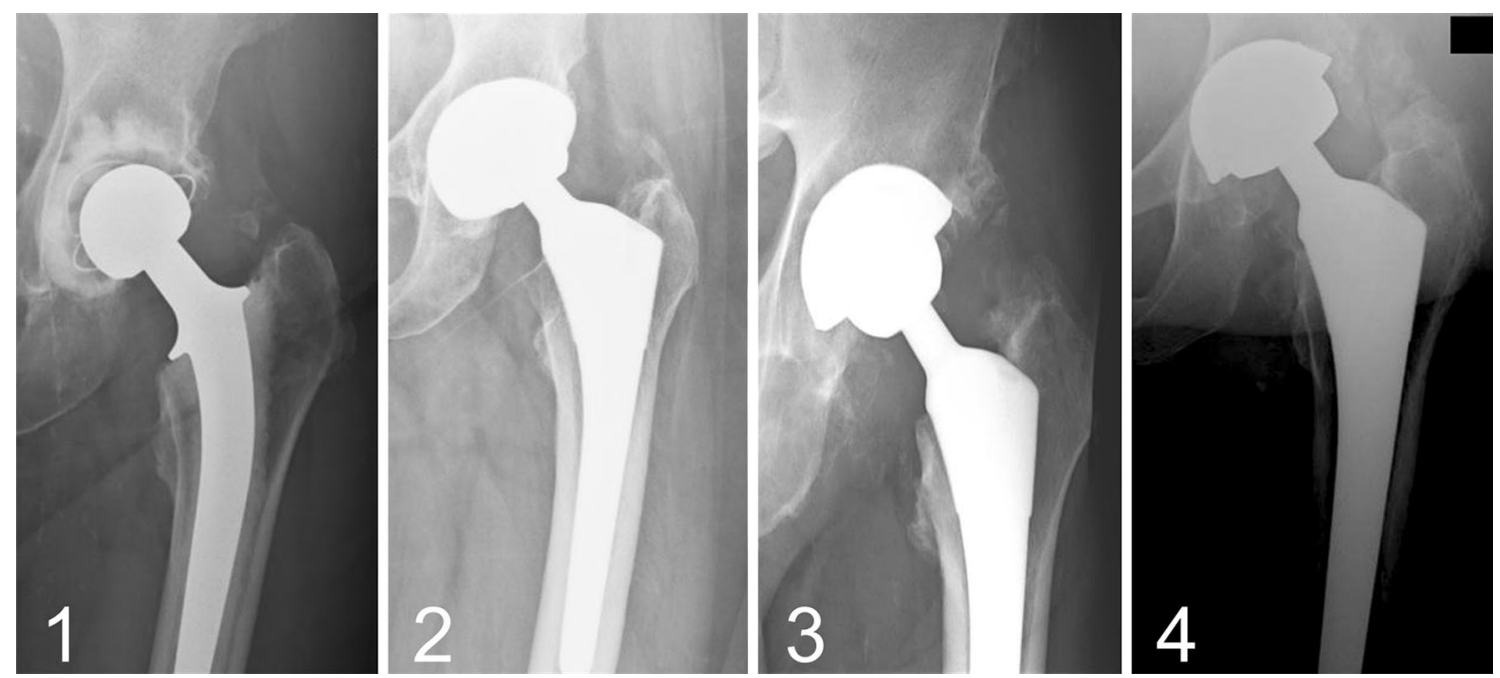

Fig. 1 Brooker's classification (classes 1-4) of HO after hip arthroplasty 
Table 2 Anatomical classification of HO from Schmidt and Hackenbrock [16]

\begin{tabular}{ll}
\hline Score & Specification/region \\
\hline 0 & No HO on anteroposterior and standard lateral view of the hip \\
I & HO strictly below the tip of the greater trochanter \\
II & HO below and above the tip of the greater trochanter \\
III & HO strictly above the tip of the greater trochanter \\
\hline
\end{tabular}

Table 3 Surgery-related variables evaluated

\begin{tabular}{ll}
\hline $\begin{array}{l}\text { Gender } \\
\text { Femoral stem fixation method }\end{array}$ & $\begin{array}{l}\text { Age at operation } \\
\text { Femoral head } \\
\text { material }\end{array}$ \\
$\begin{array}{l}\text { Femoral head size } \\
\text { Use of pulsed lavage }\end{array}$ & $\begin{array}{l}\text { Anaesthetic type } \\
\text { brush }\end{array}$ \\
Anti-thrombosis therapy & $\begin{array}{c}\text { Length of operation } \\
\text { (min) }\end{array}$ \\
Blood loss (cc) & $\begin{array}{c}\text { Incision length at } \\
\text { start }(\mathrm{cm})\end{array}$ \\
Incision length at end (cm) & Fat depth $(\mathrm{cm})$ \\
Incision length group (group I $>10 \mathrm{~cm}$, group & \\
II $\leq 10 \mathrm{~cm})$ & \\
\hline
\end{tabular}

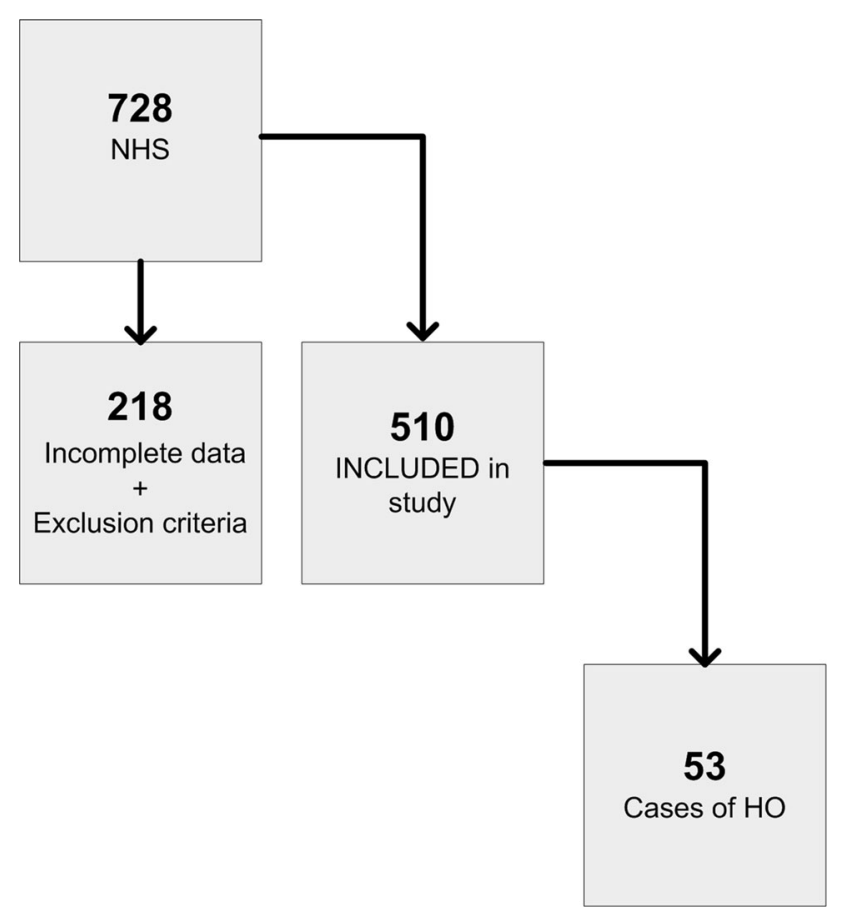

Fig. 2 A flow diagram of patient inclusion

common femoral head material $(321 ; 62.9 \%)$ with ceramic accounting for the remaining 189 (37.1\%). The Biomet Biometric-M2A(metal)/Exceed ABT(ceramic) was the commonest combination of prosthetic design $(65.1 \%)$.
Table 4 HO cases classified into Brooker grade

\begin{tabular}{lcc}
\hline Brooker grade & Frequency & \% of overall cohort \\
\hline 1 & 40 & 8.1 \\
2 & 5 & 1.0 \\
3 & 7 & 1.4 \\
4 & 1 & 0.2 \\
Total & 53 & 10.7 \\
\hline
\end{tabular}

Table 5 Categorical data statistics

\begin{tabular}{|c|c|c|c|c|}
\hline Variable & Total & $\begin{array}{l}\mathrm{HO} \\
\text { present }\end{array}$ & $\begin{array}{l}\text { HO not } \\
\text { present }\end{array}$ & $p$ value \\
\hline \multicolumn{5}{|l|}{ Gender } \\
\hline Male & 221 & 30 & 191 & \multirow[t]{2}{*}{$0.027 *$} \\
\hline Female & 289 & 23 & 266 & \\
\hline \multicolumn{5}{|l|}{ Femur fixation } \\
\hline Cemented & 121 & 15 & 106 & \multirow[t]{2}{*}{0.117} \\
\hline Uncemented & 389 & 38 & 351 & \\
\hline \multicolumn{5}{|l|}{ Femoral head material } \\
\hline Metal & 321 & 35 & 286 & \multirow[t]{2}{*}{0.450} \\
\hline Ceramic & 189 & 19 & 170 & \\
\hline \multicolumn{5}{|l|}{ Anaesthetic type } \\
\hline General anaesthesia & 344 & 36 & 308 & \multirow[t]{3}{*}{0.316} \\
\hline Spinal anaesthesia & 142 & 17 & 125 & \\
\hline Epidural anaesthesia & 24 & 0 & 24 & \\
\hline \multicolumn{5}{|l|}{ Pulsed lavage } \\
\hline Yes & 90 & 13 & 77 & \multirow[t]{2}{*}{0.084} \\
\hline No & 420 & 40 & 380 & \\
\hline
\end{tabular}

* Significant at $p<0.05$

Surgical variables measured are summarised in Tables 5 and 6.

Male patients were statistically more likely to develop HO $(p=0.027)$. Longer operations, $>60 \mathrm{~min}$, caused higher grades of $\mathrm{HO}(p=0.047)$. Incision length was positively correlated with the extent of HO. HO was limited to areas above the greater trochanter (Schmitt grade 3) in smaller incisions $(p=0.007)$. Incisions $>10 \mathrm{~cm}$ resulted in more widespread HO formation $(p=0.021)$. No other significant results were found, including prosthetic design or material.

\section{Discussion}

This study has shown that smaller incisions limit the extent of HO that appears within 1 year post-total hip arthroplasty, using the posterior approach, in a case series of 510 patients. The overall rate of HO was $10.4 \%$. In addition, 
Table 6 Scalar data statistics

\begin{tabular}{|c|c|c|c|}
\hline Variable & Value & $\begin{array}{l}\text { Correlation with } \\
\text { HO grade } \\
\text { (Brooker) }\end{array}$ & $\begin{array}{l}\text { Correlation with } \\
\text { HO extent } \\
\text { (Schmidt) }\end{array}$ \\
\hline \multicolumn{4}{|c|}{ Age (years) } \\
\hline Mean & 65.81 & 0.558 & 0.207 \\
\hline Range & $21.8-93.95$ & & \\
\hline SD & 11.65 & & \\
\hline \multicolumn{4}{|l|}{$\begin{array}{l}\text { Blood loss } \\
\quad(\mathrm{ml})\end{array}$} \\
\hline Median & 300 & 0.523 & 0.208 \\
\hline Range & $0-7000$ & & \\
\hline SD & 202 & & \\
\hline \multicolumn{4}{|c|}{$\begin{array}{l}\text { Operative } \\
\text { time (min) }\end{array}$} \\
\hline Median & 60 & $0.047 *$ & 0.990 \\
\hline Range & $35-200$ & & \\
\hline SD & 15.68 & & \\
\hline \multicolumn{4}{|l|}{$\begin{array}{l}\text { Fat depth } \\
\quad(\mathrm{cm})\end{array}$} \\
\hline Median & 3 & 0.902 & 0.149 \\
\hline Range & $0-12$ & & \\
\hline SD & 1.59 & & \\
\hline \multicolumn{4}{|c|}{$\begin{array}{l}\text { Incision } \\
\text { length }(\mathrm{cm})\end{array}$} \\
\hline Median & 10 & 0.620 & $0.007 *$ \\
\hline Range & $7-30$ & & \\
\hline SD & 3.45 & & \\
\hline \multicolumn{4}{|c|}{$\begin{array}{l}\text { Femoral } \\
\text { head size } \\
(\mathrm{mm})\end{array}$} \\
\hline Median & 38 & 0.912 & 0.495 \\
\hline Range & $25-56$ & & \\
\hline SD & 4.15 & & \\
\hline \multicolumn{4}{|c|}{$\begin{array}{l}\text { Acetabular } \\
\text { diameter } \\
(\mathrm{mm})\end{array}$} \\
\hline Median & 52 & 0.817 & 0.490 \\
\hline Range & $28-66$ & & \\
\hline SD & 4.0 & & \\
\hline
\end{tabular}

* Significant at $p<0.05$

longer operations increased the severity of $\mathrm{HO}$ and male gender was associated with higher rates of $\mathrm{HO}$.

The HO incidence in this study of $10.4 \%$ is comparable with the lower end of previous published ranges, 8-90\% $[3,4]$. The number of THAs performed in the UK in 2013 was over 80,000 [18] and is expected to rise year on year with an ageing population with increased mobility demands. The number of HO-affected hips following THA will also subsequently rise. Literature demonstrates a significant reduction in range of motion gain due to arthroplasty seen in patients who develop Brooker grades 3 and $4 \mathrm{HO}$ [6]. As $15 \%$ of our HO cohort developed these grades, primary prevention, prophylaxis or limiting the extent of $\mathrm{HO}$ is therefore necessary. Anti-inflammatory medication and radiation therapy have been proven to reduce the formation and recurrence in high-risk groups [1922]. However, both modalities may be contraindicated in an ageing patient. Research demonstrates that pro-inflammatory chemokines and cytokines are responsible for induction of osteoblast activity [11-13, 23]. Inflammation and tissue damage/ischaemia are therefore likely to be the key in the formation of HO.

Gender [24], comorbidities [8], genetic susceptibility $[25,26]$ and HO formation with previous surgery are known risk factors for $\mathrm{HO}$ formation; these are beyond the surgeon's control. Furthermore, concerns exist that localised causes of ischaemia and increased lactate levels render tissues to an increased risk of HO [16]. We explored surgery-related factors and intra-operative variables that can be controlled which may contribute to the inflammatory response amplitude. Incision length, tissue dissection and subsequent localised trauma and ischaemia, blood loss, anaesthetic type and length of surgery may all contribute to the local inflammatory response. Pulsed lavage may also spread osteoblast precursors, thereby creating an osteoconductive environment. It could be argued that mini-incision THA either reduces the "zone of injury" to the skin and underlying soft tissues and subsequent risk of $\mathrm{HO}$ formation or increases the risk due to increased tension on the wounds and soft tissues by the retractors. This work provides evidence for the former, but not the latter. Whilst $10 \mathrm{~cm}$ is regarded as the cut-off between standard and mini-incision, it is the deeper muscle and soft dissection that is most relevant for the formation of HO [27].

The main limitation with this study is that this is retrospective cohort data. In the comparison of groups where the incision is greater than the median of $10 \mathrm{~cm}$, the incision is occasionally enlarged due to operative necessity and not surgeon's choice. However, inter-operative variables are minimised by our single-surgeon cohort.

Our results demonstrate that differences in intra-operative practice do not contribute significantly to the factors that initiate HO formation. It is therefore an "all or nothing" event where the act of surgery itself, no matter how extensive, is the contributing factor. However, the data suggest that the surgeon may control the extent and nature of HO formation by limiting the incision length and if possible the length of the operation. This may be advantageous in trying to reduce the numbers of patients affected by the higher grades of $\mathrm{HO}$ and subsequently loss of range of motion. Our findings regarding the relationship between gender and $\mathrm{HO}$ formation mirror that which has been previously reported. Minimal invasive surgery, fixation 
method, prosthetic material, femoral head size and material do not correlate with $\mathrm{HO}$ formation.

\section{Conclusion}

An HO rate of $10.2 \%$ in our cohort, where minimal incisions are used (median $10 \mathrm{~cm}$ ), is towards the lower end of the range of published rates of $\mathrm{HO}$. We therefore conclude that the posterior minimal incision is a safe approach to use with regard to the formation of HO. Furthermore, the minimal incision technique reduces the extent of $\mathrm{HO}$ found in the soft tissue.

Conflict of interest Each author declares that no conflict of interest exists in research related to this piece of work.

Open Access This article is distributed under the terms of the Creative Commons Attribution 4.0 International License (http:// creativecommons.org/licenses/by/4.0/), which permits unrestricted use, distribution, and reproduction in any medium, provided you give appropriate credit to the original author(s) and the source, provide a link to the Creative Commons license, and indicate if changes were made.

\section{References}

1. Kaplan FS, Glaser DL, Hebela N, Shore EM (2004) Heterotopic ossification. J Am Acad Orthop Surg 12(2):116-125

2. Riegler HF, Harris CM (1976) Heterotopic bone formation after total hip arthroplasty. Clin Orthop Relat Res 117:209-216

3. Amstutz HC (1970) Complications of total hip replacement. Clin Orthop Relat Res 72:123-137

4. Rosendahl S, Christoffersen JK, Norgaard M (1977) Para-articular ossification following hip replacement. 70 arthroplasties ad modum Moore using McFarland's approach. Acta Orthop Scand 48(4):400-404

5. Brooker AF, Bowerman JW, Robinson RA, Riley LH Jr (1973) Ectopic ossification following total hip replacement. Incidence and a method of classification. $J$ Bone Joint Surg Am 55(8):1629-1632

6. Ahrengart L, Lindgren U (1989) Functional significance of heterotopic bone formation after total hip arthroplasty. J Arthroplasty $4(2): 125-131$

7. Iorio R, Healy WL (2002) Heterotopic ossification after hip and knee arthroplasty: risk factors, prevention, and treatment. J Am Acad Orthop Surg 10(6):409-416

8. Kjaersgaard-Andersen P, Ritter MA (1991) Prevention of formation of heterotopic bone after total hip arthroplasty. J Bone Joint Surg Am 73(6):942-947

9. Edwards DS, Clasper JC (2014) Heterotopic ossification: a systematic review. J R Army Med Corps. doi:10.1136/jramc-2014000277
10. Purtill JJ, Eng K, Rothman RH, Hozack WJ (1996) Heterotopic ossification. Incidence in cemented versus cementless total hip arthroplasty. J Arthroplasty 11(1):58-63

11. Canalis E (1981) Effect of platelet-derived growth factor on DNA and protein synthesis in cultured rat calvaria. Metabolism 30(10):970-975

12. Canalis E, Raisz LG (1979) Effect of epidermal growth factor on bone formation in vitro. Endocrinology 104(4):862-869

13. Centrella M, McCarthy TL, Canalis E (1987) Transforming growth factor beta is a bifunctional regulator of replication and collagen synthesis in osteoblast-enriched cell cultures from fetal rat bone. J Biol Chem 262(6):2869-2874

14. Hock JM, Centrella M, Canalis E (1988) Insulin-like growth factor I has independent effects on bone matrix formation and cell replication. Endocrinology 122(1):254-260

15. Evans KN, Forsberg JA, Potter BK, Hawksworth JS, Brown TS, Andersen R et al (2012) Inflammatory cytokine and chemokine expression is associated with heterotopic ossification in highenergy penetrating war injuries. J Orthop Trauma 26(11):e204e213

16. Ahrengart L, Sahlin K, Lindgren U (1987) Myositis ossificans after total hip replacement and perioperative muscle ischemia. J Arthroplasty 2(1):65-69

17. Schmidt J, Hackenbroch MH (1996) A new classification for heterotopic ossifications in total hip arthroplasty considering the surgical approach. Arch Orthop Trauma Surg 115(6):339-343

18. [1st December 2014]. http://www.njrcentre.org.uk/

19. Vavken P, Castellani L, Sculco TP (2009) Prophylaxis of heterotopic ossification of the hip: systematic review and metaanalysis. Clin Orthop Relat Res 467(12):3283-3289

20. Haran M, Bhuta T, Lee B (2004) Pharmacological interventions for treating acute heterotopic ossification. Cochrane Database Syst Rev (4):CD003321

21. Fransen M, Neal B (2004) Non-steroidal anti-inflammatory drugs for preventing heterotopic bone formation after hip arthroplasty. Cochrane Database Syst Rev (3):CD001160

22. Vasileiadis GI, Sioutis IC, Mavrogenis AF, Vlasis K, Babis GC, Papagelopoulos PJ (2011) COX-2 inhibitors for the prevention of heterotopic ossification after THA. Orthopedics 34(6):467

23. Schurch B, Capaul M, Vallotton MB, Rossier AB (1997) Prostaglandin E2 measurements: their value in the early diagnosis of heterotopic ossification in spinal cord injury patients. Arch Phys Med Rehabil 78(7):687-691

24. Eggli S, Woo A (2001) Risk factors for heterotopic ossification in total hip arthroplasty. Arch Orthop Trauma Surg 121(9):531-535

25. Larson JM, Michalski JP, Collacott EA, Eltorai D, McCombs CC, Madorsky JB (1981) Increased prevalence of HLA-B27 in patients with ectopic ossification following traumatic spinal cord injury. Rheumatol Rehabil 20(4):193-197

26. Moll JM, Haslock I, Macrae IF, Wright V (1974) Associations between ankylosing spondylitis, psoriatic arthritis, Reiter's disease, the intestinal arthropathies, and Behcet's syndrome. Medicine (Baltimore) 53(5):343-364

27. Berstock JR, Blom AW, Beswick AD (2014) A systematic review and meta-analysis of the standard versus mini-incision posterior approach to total hip arthroplasty. J Arthroplasty 29(10):1970-1982 